\title{
OTOLITH SHAPE DISCRIMINATION OF LIZA RAMADA (ACTINOPTERYGII: MUGILIFORMES: MUGILIDAE) FROM MARINE AND ESTUARINE POPULATIONS IN TUNISIA
}

\author{
Manel REBAYA*1, Abderraouf BEN FALEH ${ }^{1}$, Hassen ALLAYA ${ }^{1}$, Maïssa KHEDHER ${ }^{1}$, Mouna \\ TROJETTE ${ }^{1}$, Bochra MARSAOUI ${ }^{1}$, Manel FATNASSI ${ }^{1}$, Abdellah CHALH $^{2}$, \\ Jean-Pierre QUIGNARD ${ }^{3}$, and Monia TRABELSI ${ }^{1}$
}

${ }^{1}$ Unité de Biologie Marine, Faculté des Sciences, Université Tunis El Manar, Campus Universitaire, Manar II, Tunis, Tunisie

${ }^{2}$ Unité de génétique des populations et ressources biologiques, Faculté des Sciences, Campus Universitaire, Manar II, Tunis, Tunisie

${ }^{3}$ Laboratoire d'Ichtyologie, Université Montpellier II, place Eugène Bataillon, Montpellier, France

Rebaya M., Ben Faleh A.R., Allaya H., Khedher M., Trojette M., Marsaoui B., Fatnassi M., Chalh A., Quignard J.-P., Trabelsi M. 2017. Otolith shape discrimination of Liza ramada (Actinopterygii: Mugiliformes: Mugilidae) from marine and estuarine populations in Tunisia. Acta Ichthyol. Piscat 47 (1): 13-21.

Background. The thinlip grey mullet, Liza ramada (Risso, 1810), is widespread in Tunisia. Despite its economic importance, the stock discrimination of this fish is poorly understood. The aim of this study is to investigate, for the first time, the stock discrimination of this species for two Tunisian populations based on the otolith shape, using different statistical approaches.

Materials and methods. The specimens of L. ramada were collected during three months (from March to May 2013) at two sampling sites: the marine (Cap Zebib sea resort) and the estuarine (Mellegue Dam) in Tunisia. We analysed sagittal otolith shape variation for 120 individuals ( 60 fish of each study site comprising 30 males and 30 females) for both sexes (males and females) and two sides (left and right otolith) for each specimen.

Results. Statistical-and discriminant function analysis of the sagittal otolith shape clearly demonstrated statistically significant differences from the two populations. These results were also confirmed by highly statistically significant difference between otolith shape (left and right) for both sexes. An asymmetry was detected when comparing otoliths of the same side (RR-LL) between different sampling sites.

Conclusion. The shape variability of otolith between these two sampling sites is probably correlated with local environmental and ecological factors.

Keywords: sagitta otolith, morphology, asymmetry, fisheries management, Cap Zebib sea resort, Mellegue Dam

\section{INTRODUCTION}

The thinlip grey mullet, Liza ramada (Risso, 1810), is widely distributed in the eastern part of the Atlantic. The range of this fish stretches from the southern coast of Norway to Morocco, including the Mediterranean and the Black Sea (Jonsson and Jonsson 2008). This euryhaline and pelagic species occurs in different habitats (estuaries, deltas, lagoons, brackish waters, and marine areas of full salinity (Kasımoğlu and Yılmaz 2012). It's noteworthy that this fish tolerates the extreme conditions of salinity and withstands sudden changes in water quality (Papasotiropoulos et al. 2002).
In Tunisia, six species belonging to the family Mugilidae were previously described: Mugil cephalus Linnaeus, 1758; Chelon labrosus (Risso, 1827); Liza aurata (Risso, 1810); Liza ramada (Risso, 1810); Liza saliens (Risso, 1810); and Oedalechilus labeo (Cuvier, 1829) (see Blel et al. 2008). The annual production of Mugilidae in Tunisia is important and has been increasing in recent years (Fehri-Bedoui et al. 2002). Among these species, the thinlip grey mullet (grey mullet thereafter) is one of the target fish species of commercial fishing along the coast of Tunisia (Masmoudi et al. 2001).

"Correspondence: Dr M. Rebaya, Unité de Biologie Marine UR 13 ES 36, Faculté des Sciences de Tunis, Université Tunis El Manar, Tunis, Tunisie, phone: +216 94 520 552, e-mail: (MR) mannoula_01@hotmail.com,_(ABF) benfalahabdelraouf@yahoo.fr,, (HA) hassen.allaya@yahoo.fr, (MK) khedhermaissa@yahoo.fr, (MT) mayna_bio@hotmail.com, (BM) marsaouibochra@gmail.com, (MF) manel.ft@gmail.com, (AC) abdellah.chalh@gmail.com, (JPQ) qjp2@wanadoo.fr, (MT) atherina2002@yahoo.fr. 
In view of its economic importance, the grey mullet has been investigated in different geographical regions, focusing on its biology, ecology, parasitology, genetics, biochemical composition, heavy metal concentrations, and age determination (Merella and Garippa 2001, Almeida 2003, Yacoub and Abdel Satar 2003, Nirchio et al. 2005, Boglione et al. 2006, Glamuzina et al. 2007, Bahnasawy et al. 2009, El-Ghobashy 2009, Rabeh et al. 2010, El Zaeem 2011, Dakrory et al. 2012). Additionally, age of grey mullet was determined by different methods using scales, otoliths, opercular bones, vertebrae, and dorsal fin rays from the Mersin Bay (Göçer and Ekingen 2005). Also Almeida et al. (1995) used otolith analysis for the purpose of age determination of this species in the Tagus River in Portugal.

The otolith is considered as a true biological and environmental archive with a potential to facilitate reconstruction of environmental parameters (temperature, salinity) and life history traits of fish (age, growth, reproduction, and migration) (Radhakrishan et al. 2009).

Sagittal otoliths have some phenotypic plasticity inter and/or intra-specific and inter-and/or intra-populations (Lombarte and Lleonart 1993, Annabi et al. 2013). This property has been used very often in the discrimination of populations evolved in different environmental conditions (temperature, depth, substrate) taking into account possible confounding variables (sex, size) (Volpedo and Vaz-dos-Santos 2015). Therefore, analysis of the morphology of otoliths is a very powerful tool to identify different fish species (Furlani et al. 2007). This tool helped to distinguish different stocks of fish (Jónsdóttir et al. 2006). The identification of mugilid species is important for local fisheries management (Mehanna 2006). In fact, Reichenbacher and Reichard (2014) reported the first analysis of inter- and intraspecific otolith variation within a genus belonging to the Aplocheiloidei. They analysed five species of the genus Nothobranchius Peters, 1868 from Tanzania and southern Mozambique, obtained from wild and wild-derived captive populations.

According to El-Dahhar et al. (2013) grey mullet, being collected in marine, brackish and fresh waters, makes this fish a good model for research. The species that breed only in seawater is currently under extensive rearing in some Tunisian dams from fry collected along the coast (Abdennadher et al. 2003). The stock discrimination of grey mullet species is poorly understood up to date.

The aim of this study was to evaluate by using otolith shape, the stock structure of grey mullet from two ecologically different sites in Tunisia - marine (saltwater) and estuarine (freshwater). The marine site was the Cap Zebib sea resort, while the estuarine site was the Mellegue Dam.

\section{MATERIAL AND METHODS}

A total of 120 specimens of grey mullet, Liza ramada, were collected between March and May 2013 from two different sampling sites differing is water salinity: the marine (Cap Zebib sea resort) and the estuarine (above the Mellegue Dam) (Fig. 1). The fishing gear was a gillnet of 50 to $70 \mathrm{~m}$ in length and 3 to $6 \mathrm{~m}$ meshes of height. A total of 60 fish for each station were examined, in equal proportion for each sex (30 males and 30 females). Common names of fishes used in this paper follow FishBase (Froese and Pauly 2016).

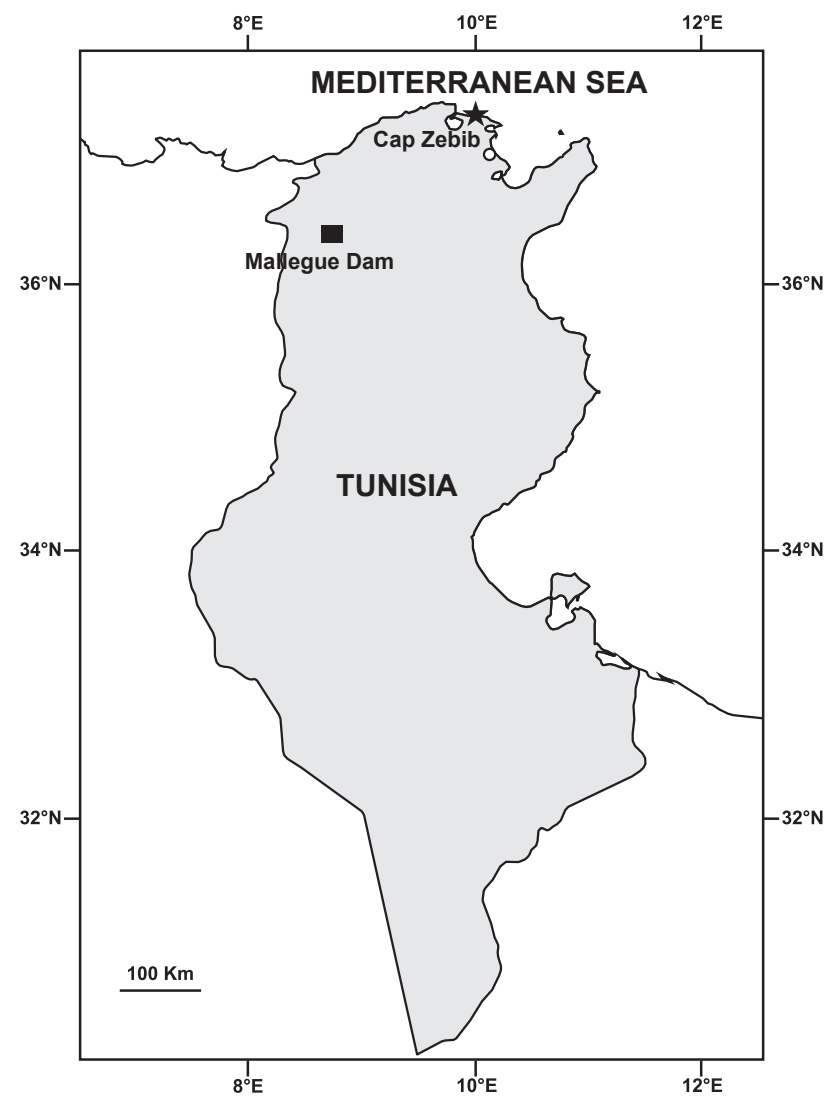

Fig. 1. Sampling sites of thinlip grey mullet, Liza ramada, in Tunisia (Cap Zebib and Mellegue Dam)

The Mellegue Dam $\left(36^{\circ} 18^{\prime} 51^{\prime \prime} \mathrm{N}, 8^{\circ} 42^{\prime} 08^{\prime \prime} \mathrm{E}\right)$ is located about $7 \mathrm{~km}$ west of the city of Nebeur (Kef). The dam height and length are $65 \mathrm{~m}$ and $470 \mathrm{~m}$, respectively and the mean annual precipitation in this area is approximately $400 \mathrm{~mm}$. The waters of the river are very muddy, especially in times of flood. The salinity reported by Bahri (1993) was $2.0 \% 0^{-}-2.5 \%{ }^{*}$. At this sampling site, grey mullet is abundant between January and May (Ben Mammou and Louati 2006).

Cap Zebib is located on the northern coast of Tunisia $\left(37^{\circ} 15^{\prime} 41.40^{\prime \prime} \mathrm{N}, 10^{\circ} 04^{\prime} 24.86^{\prime \prime} \mathrm{E}\right)$ and characterized by a pristine coastline, low human activity, and strong water currents (Belgacem et al. 2013). The salinity is fairly constant $(36.5 \%$ o $-37 \%$ o). This sea is a spawning ground for a number of teleost fishes (Turki and Ktari-Chakroun 1985).

We used a fish measuring board to measure the total length (TL) and standard length (SL) and a precision balance (Sartorius) to determine the total weight (TW) of each fish specimen (see Table 1). 
Length and weight of specimens of thinlip grey mullet, Liza ramada, from Tunisia

\begin{tabular}{|c|c|c|c|c|c|}
\hline \multirow{2}{*}{$\begin{array}{l}\text { Sampling site } \\
\text { and sex }\end{array}$} & \multirow{2}{*}{$n$} & \multicolumn{2}{|c|}{ Standard length [mm] } & \multicolumn{2}{|c|}{ Total weight $[\mathrm{g}]$} \\
\hline & & Mean \pm SD & Range & Mean \pm SD & Range \\
\hline Cap Zebib M & 30 & $194.73 \pm 12.47$ & $175-231$ & $145.54 \pm 29.52$ & $110.02-250.32$ \\
\hline Cap Zebib F & 30 & $194.83 \pm 10.00$ & $180-228$ & $142.29 \pm 21.61$ & $107.53-217.87$ \\
\hline Mellegue Dam M & 30 & $232.93 \pm 21.67$ & $190-274$ & $221.47 \pm 57.87$ & $125.06-331.73$ \\
\hline Mellegue Dam F & 30 & $250.63 \pm 19.75$ & $204-280$ & $283.12 \pm 64.03$ & $163.74-407.52$ \\
\hline
\end{tabular}

$n=$ number of fish $\mathrm{SD}=$ standard deviation, $\mathrm{M}=$ males, $\mathrm{F}=$ females.

The otolith extraction protocol was proposed by Panfili et al. (2003). The otoliths were photographed by a digital camera (Samsung PL210 with the resolution of 14.2 megapixels and optical zoom 10×) under a microscope. The image analysis on a computer screen allowed us to evaluate each image and store it in a database. The photographs of all otoliths were processed by Adobe Photoshop CS6 (Fig. 2). Subsequently, the images were processed by the Shape software version 1.3 which created 20 harmonies for each otolith (each otolith represents an individual). Each harmony was composed of four coefficients, the so called Fourier coefficients ( $A, B, C$, and $D$ ) corresponding to the values of the projection of the binary image on the axes $X$ and $Y$ (Kuhl and Giardina 1982), resulting in 80 coefficients per individual.

The morphological variation in individuals was based on statistical analysis of the parameters from the developments in Fourier series. Elliptic Fourier analysis (EFA) was used to perform mathematical analyses of the otolith shape. This technique describes the silhouette called harmonic. Each harmonic is characterized by four Fourier coefficients $(A, B, C$, and $D)$ which calculates the Fourier power (FP), the percentage of Fourier power (FP\%), and the cumulative percentage of the Fourier power $\left(\mathrm{FP}_{n} \%\right.$ cumulative). The respective formulas are provided below (Crampton 1995, Trojette et al. 2015):

$$
\begin{gathered}
\mathrm{FP}=\left(A_{n}^{2}+B_{n}^{2}+C_{n}^{2}+D_{n}^{2}\right)^{-2} \\
\mathrm{FP} \%=100 \mathrm{FP}_{n}\left(\sum_{1}^{n} \mathrm{FP}_{n}\right)^{-1} \\
\mathrm{FP}_{n} \%_{c}=\sum_{1}^{n} \mathrm{FP}_{n} \%
\end{gathered}
$$

The statistical analysis of the otolith shape was performed using EFA describing the shape of the otolith. To have the most accurate otolith shape, the percentage of Fourier power was calculated to determine the number of necessary and sufficient harmonics. Therefore, this number was fixed at 20 and a total of 180 replicates were obtained (60 observations for each study site).

Multivariate analysis (Wilks's Lambda test) was performed for the treatment of all otolith synchronous parameters.

To assess the differences between our different batches of otoliths, we performed multivariate analysis that enables the processing of all the otolith parameters at the same time. In addition, discriminant function analysis (DFA) was performed on shapes indices in order to illustrate the differences and similarities between the observed groups and optimize the existing variability. For this analysis, the factorial graphic designs allow visualizing individuals and variables. Various indicators and tests were also used in order to estimate the reliability of our results. All statistical analyses were performed using XLSTAT (2010) software.

\section{RESULTS}

The Wilks's Lambda test (Rao approximation) revealed the presence of statistically significant differences between the two sampling sites $(P<0.0001)$ (Table 2). The matrix of Mahalanobis distances between the left and right otolith for the populations of Cap Zebib and Mellegue Dam as well as between the left and right otolith of both populations is given in Table 3 .

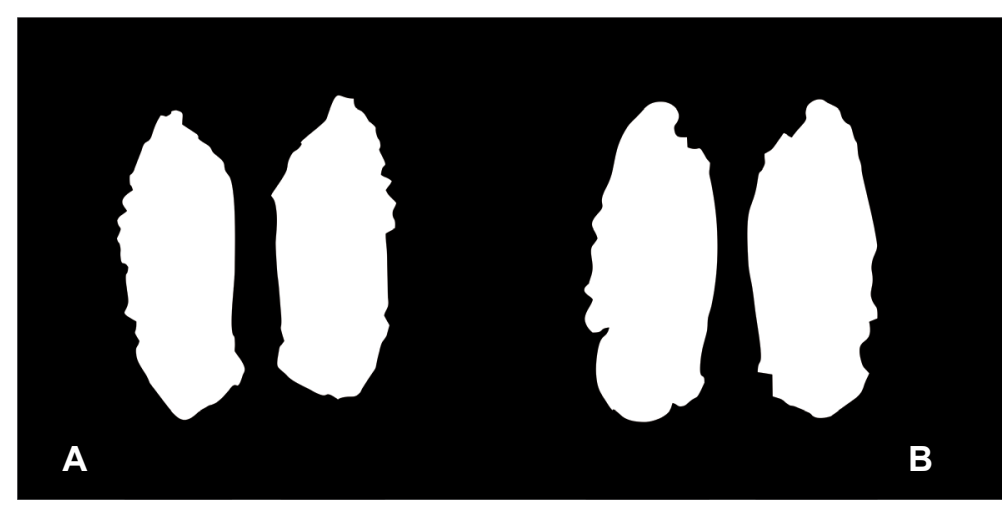

Fig. 2. Otolith images of thinlip grey mullet, Liza ramada, from Tunisia, processed using Photoshop software; $\mathbf{A}=$ Cap Zebib, $\mathbf{B}=$ Mellegue Dam 
Table 2 left-male) was 14.873, respectively (Table 3 ). The values

Wilks's Lambda test of the distance approximation between populations of the thinlip grey mullet, Liza ramada, from Tunisia (Rao approximation)

\begin{tabular}{lc}
\hline \multicolumn{1}{c}{ Parameter } & Value \\
\hline Lambda & 0.011 \\
$F$ (Observed value) & 1.874 \\
$F$ (Critical value) & 1.128 \\
DDL1 & 539 \\
DDL2 & 11022 \\
$P$-value & $<0.0001$ \\
Alpha & 0.05 \\
\hline
\end{tabular}

The respective distances between the female and male otoliths (left-right) for Cap Zebib were: 12.205 and 11.570, and those for Mellegue Dam were 16.433 and 11.279. This result showed that the Mahalanobis distance between the individuals representing the two populations was similar except for the females of Mellegue Dam. Moreover, Mahalanobis distance between the otoliths of the two populations: Mellegue Dam-right-female and Cap Zebib-right-female was 22.415 and between Mellegue Dam-right-male and Cap Zebib-right-male was 22.152. In addition, this distance between Mellegue Dam-left-female and Cap Zebib-Left-female was 14.084 and between Mellegue Dam-left-male and Cap Zebib- quoted for the distances between the two populations were high and clearly differentiated them.

The Mahalanobis and Fisher distances provided the same results. In the same population, the respective Fisher distance values between the female and male otoliths (L-R) for Cap Zebib were 0.830 and 0.858, while for Mellegue Dam they amounted to 1.844 and 1.009 . The highest distances were revealed for the females of Mellegue Dam, while the lowest were recorded for females of Cap Zebib and for males and females of Mellegue Dam. Those between the otoliths of the two populations: Mellegue Dam-right-female, Cap Zebibright-female and Mellegue Dam-right-male, Cap Zebibright-male were: 2.936 and 2.902, respectively. Thus the distance between Mellegue Dam-left-female, Cap Zebibleft-female and Mellegue Dam-left-male, Cap Zebibleft-male were 1.845 and 1.948, respectively (Table 4). The values provided for the distances between the two populations (right-right/left-left) were close to each other and showed clear difference between them.

In the same population, $P$-value of Fisher distances (left-right) was highly statistically significant $(P<$ 0.0001 ) for the females originating in Mellegue Dam only (case of left-right asymmetry). The $P$ values were also significant $(P<0.05)$ for the females of Cap Zebib $(P=$ $0.007)$, the males $(P=0.015)$, and the males of Mellegue

Table 3

Pairwise of Mahalanobis distances between side and sex of otolith of thinlip grey mullet, Liza ramada, from Tunisia

\begin{tabular}{ccccccccc}
\hline & BFD & BFG & BMD & BMG & MFD & MFG & MMD & MMG \\
\hline BFD & 0 & 16.433 & 14.078 & 16.074 & 22.415 & 25.215 & 25.942 & 34.737 \\
BFG & & 0 & 13.647 & 7.706 & 24.248 & 14.084 & 27.341 & 19.577 \\
BMD & & & 0 & 11.279 & 19.482 & 19.586 & 22.152 & 22.938 \\
BMG & & & & 0 & 20.965 & 12.435 & 22.810 & 14.873 \\
MFD & & & & & 0 & 12.205 & 6.334 & 15.047 \\
MFG & & & & & 0 & 11.390 & 6.548 \\
MMD & & & & & & 0 & 11.570 \\
MMG & & & & & & & & 0 \\
\hline
\end{tabular}

$\mathrm{BFD}=$ dam female right, $\mathrm{BFG}=$ dam female left, $\mathrm{BMD}=$ dam male right, $\mathrm{BMG}=$ dam male left, $\mathrm{MFD}=$ sea female right, $\mathrm{MFG}=$ sea female left, $\mathrm{MMD}=$ sea male right, $\mathrm{MMG}=$ sea male left.

Table 4

Fisher's distances between two sides and sexes of thinlip grey mullet, Liza ramada, specimens from Tunisia

\begin{tabular}{ccccccccc}
\hline & BFD & BFG & BMD & BMG & MFD & MFG & MMD & MMG \\
\hline BFD & 0 & 2.153 & 1.844 & 2.105 & 2.936 & 3.303 & 3.398 & 4.550 \\
BFG & & 0 & 1.788 & 1.009 & 3.176 & 1.845 & 3.581 & 2.564 \\
BMD & & & 0 & 1.477 & 2.552 & 2.566 & 2.902 & 3.005 \\
BMG & & & & 0 & 2.746 & 1.629 & 2.988 & 1.948 \\
MFD & & & & & 0 & 1.599 & 0.830 & 1.971 \\
MFG & & & & & & 0 & 1.492 & 0.858 \\
MMD & & & & & & 0 & 1.516 \\
MMG & & & & & & & & 0 \\
\hline
\end{tabular}

$\mathrm{BFD}=$ dam female right, $\mathrm{BFG}=$ dam female left, $\mathrm{BMD}=$ dam male right, $\mathrm{BMG}=$ dam male left, $\mathrm{MFD}=$ sea female right, $\mathrm{MFG}=\mathrm{sea}$ female left, $\mathrm{MMD}=$ sea male right, $\mathrm{MMG}=$ sea male left. 
$\operatorname{Dam}(P=0.021)$ (case of left-right asymmetry) (see Table 5 ). Moreover, the sexual dimorphism was recorded only in right side in Mellegue Dam population (for females and males right, $P=0.001$ ). However, no differences were detected between males and females of Cap Zebib population: for females and males left, $P=0.773$; for females and males right, $P=0.819$.

The results of the comparison between both samples of fish (Cap Zebib and Mellegue Dam) revealed a clear difference between the otoliths (left-right) of males and females $(P<0.05)$. The asymmetry (left-right) of otoliths revealed in this study indicates that the two populations of fish (Cap Zebib and Mellegue Dam) have different morphology of otoliths and belongs to different fish stocks.

The discriminant function analysis showed the projection of individuals on the two first axes (F1 and F2) (Fig. 3). In fact, these two discriminant axes explained $43.820 \%$ and $25.640 \%$ of total variation, respectively, and accounted for $69.460 \%$ of the total variance (Table 6 ).
The otoliths ( $\mathrm{R}-\mathrm{L}$ of each pair) of specimens from Cap Zebib were separated by F1 (male) and F2 (females) axis, while the individuals of Mellegue Dam were differentiated by the F2 (males) and F5 (females). This finding was consistent with the results revealed by Fisher- and Mahalanobis distance testes and confirms the symmetry (R-L) detected for the two sexes of the sampling sites except the males of Cap Zebib which were represented an asymmetry. The otoliths (right-right) and (left-left) for Cap Zebib and Mellegue Dam are separated by the axis F1. This result showed the asymmetry between the otoliths of the two populations, which present different morphologies.

\section{DISCUSSION}

The otolith shape variability was analysed for grey mullet in two stations: Cap Zebib Sea Resort and Mellegue Dam. In the presently reported study, the elliptic Fourier analysis based on otolith shape, revealed

Table 5

$P$-value for Fisher distances of thinlip grey mullet, Liza ramada, specimens from Tunisia

\begin{tabular}{|c|c|c|c|c|c|c|c|c|}
\hline & BFD & BFG & BMD & BMG & MFD & MFG & MMD & MMG \\
\hline BFD & 1 & $<0.0001$ & 0.001 & $<0.0001$ & $<0.0001$ & $<0.0001$ & $<0.0001$ & $<0.0001$ \\
\hline BFG & & 1 & 0.001 & 0.472 & $<0.0001$ & 0.001 & $<0.0001$ & $<0.0001$ \\
\hline BMD & & & 1 & 0.021 & $<0.0001$ & $<0.0001$ & $<0.0001$ & $<0.0001$ \\
\hline BMG & & & & 1 & $<0.0001$ & 0.005 & $<0.0001$ & 0.000 \\
\hline MFD & & & & & 1 & 0.007 & 0.819 & 0.000 \\
\hline MFG & & & & & & 1 & 0.018 & 0.773 \\
\hline MMD & & & & & & & 1 & 0.015 \\
\hline MMG & & & & & & & & 1 \\
\hline
\end{tabular}

$\mathrm{BFD}=$ dam female right, $\mathrm{BFG}=$ dam female left, $\mathrm{BMD}=$ dam male right, $\mathrm{BMG}=$ dam male left, $\mathrm{MFD}=$ sea female right, $\mathrm{MFG}=$ sea female left, $\mathrm{MMD}=$ sea male right, $\mathrm{MMG}=$ sea male left.

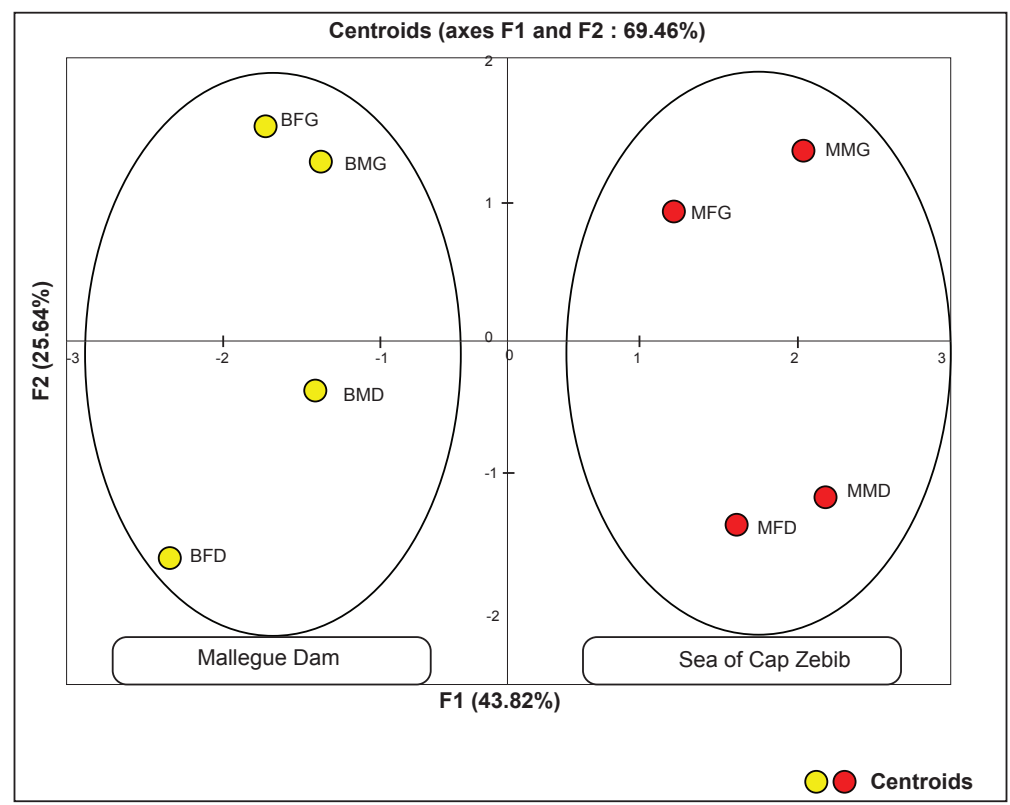

Fig. 3. Discriminant function analysis for two sexes and two sides of otoliths of thinlip grey mullet, Liza ramada, from Tunisia; Abbreviations: $\mathrm{BFD}=$ dam female right, $\mathrm{BFG}=$ dam female left, $\mathrm{BMD}=$ dam male right, $\mathrm{BMG}=$ dam male left, $\mathrm{MFD}=$ sea female right, $\mathrm{MFG}=$ sea female left, $\mathrm{MMD}=$ sea male right, $\mathrm{MMG}=$ sea male left 
Table 6 in a wide range of external salinity levels, including

Eigen values of the discrimination rate for the populations of thinlip grey mullet, Liza ramada, from Tunisia

\begin{tabular}{lccc}
\hline & Eigen value & Discrimination [\%] & \% cumuli \\
\hline F1 & 3.478 & 43.816 & 43.816 \\
F2 & 2.036 & 25.642 & 69.459 \\
F3 & 0.874 & 11.006 & 80.464 \\
F4 & 0.523 & 6.583 & 87.047 \\
F5 & 0.420 & 5.294 & 92.341 \\
F6 & 0.355 & 4.471 & 96.813 \\
F7 & 0.253 & 3.187 & 100.000 \\
\hline
\end{tabular}

the presence of two well-differentiated and distinct populations (marine and estuarine).

The discriminant function analysis showed significant differences in otolith shape between marine and estuarine populations, and significant differences in the same environment. The morphological analysis also showed a clear asymmetry between the left and right otoliths in females and males of the Mellegue Dam and Cap Zebib

The discriminant function analysis confirmed this result and revealed the presence of eight groups $(\mathrm{BFD}=$ dam female right, $\mathrm{BFG}=$ dam female left, $\mathrm{BMD}=$ dam male right, $\mathrm{BMG}=$ dam male left, $\mathrm{MFD}=$ sea female right, $\mathrm{MFG}=$ sea female left, $\mathrm{MMD}=$ sea male right, $\mathrm{MMG}=$ sea male left) with highly significant distances.

Otoliths are natural data loggers that record information at different temporal scales related to their environment (Neves et al. 2015). Hence, the differences in the morphology of otolith shape between the two populations, demonstrated in this study, were probably related to the properties of the dam reservoir environment such as food and reproductive strategies that are different from those in the marine environment (Limburg et al. 2015).

In this case, the same result was reported by Rebaya et al. (2016), which revealed the presence of two different populations of the grey mullet between two lagoon stations located in the North of Tunisia (Ghar El Melh Lagoon and Bizerte Lagoon). In addition to that, an asymmetry was detected between the otoliths of the same sex from both stations.

In this context, Avigliano et al. (2015) evaluated the potential use of otolith microchemistry $(\mathrm{Sr} \div \mathrm{Ca}$ and $\mathrm{Ba} \div \mathrm{Ca}$ ratios) to identify the silver mullet, Mugil curema Valenciennes, 1836, populations in the south-eastern Caribbean Sea. In fact, the authors mentioned above, observed the existence of different groups of in this geographic area.

However, the presence of two differentiated populations of grey mullet, in the presently reported study, is probably related to differences in physicochemical parameters of the two stations. In this way, by comparing habitat from two different sampling sites, we can assume that the distribution of grey mullet was strongly affected by the salinity. It is well documented that grey mullet well tolerates different salinities, and is capable of maintaining a stable internal osmolality fresh water and estuarine waters (Cardona 2006). In this case, grey mullet, is a species found over a wide range of salinity levels (Lafaille et al. 2002). We postulate herewith that the temperature and the turbidity were the parameters that primarily affected the distribution of grey mullet in Mellegue Dam and Cap Zebib sampling sites with relevant role for the salinity. Also Chang et al. (2004) reported that the otolith elemental composition of flathead grey mullet, Mugil cephalus, can be affected by the salinity. Campana (1999) claimed that the temperature, the major life history transitions, the somatic growth rate, the rate of crystal formation, and the water chemistry might affect the otolith variation in heterogeneous environment.

According to Fortunato et al. (2014), a clear relation between otolith size and communication strategies were described for eight mugilid species originating from the north-eastern Atlantic and the Mediterranean Sea. In the same way, the morphology of sagittal otoliths represents an adequate tool to identify the species belonging to the family Mugilidae in various geographical areas. According to the literature, the difference in the lengthweight relations of grey mullet can be explained by the numerous biotic and abiotic factors such as adequacy of the food, density of the population, and peculiarity of physical and chemical parameters of the water (Kalay et al. 2008).

In this case, the otolith morphological difference between the Cap Zebib Sea Resort and the Mellegue Dam stocks may be due to environmental differences that correspond with marine and estuarine habitats, respectively. Besides, the otolith shape differences in a same stock (left-right otoliths) in grey mullet can be attributed to environmental influences (temperature, movements of water masses, depth) (Midway et al. 2014) without excluding the genetic mutations (Trojette et al. 2014).

In this study, analysis of otolith shape revealed the presence of two differentiated populations of grey mullet from marine and estuarine environments. The comparison of the otolith morphology between the two populations showed a clear difference in shape (a left-right asymmetry) of otoliths. Based on the presently reported results, it seems likely that the differences in otolith shape of grey mullet, could be explained by environmental and physicochemical factors (temperature, salinity, water composition, etc.). This work contributes to the knowledge on the stock discrimination for grey mullet and provides useful information for studying fisheries management of this species in Tunisia.

In the future, otolith biochemical analysis will be an adequate tool for better understanding the environment physiochemical parameters affecting the otolith morphology of the two populations. Genetic investigations including mitochondrial DNA such D-loop region will also be necessary to more understand our results. 


\section{REFERENCES}

Abdennadher A., Zouiten D., Besbes R., El Abed A., Missaoui H., Ben Khemis L. 2003. Elevage larvaire $\mathrm{du}$ mulet lippu (Chelon labrosus) en conditions semi-extensives en mesocosme: croissance et developpement. Bulletin de l'INSTM, Actes des $6^{\text {èmes }}$ journées de l'ATS Mer Tunis nº́spécial 8: 33-36.

Almeida P.R. 2003. Feeding ecology of Liza ramada (Risso, 1810) (Pisces, Mugilidae) in a south-western estuary of Portugal. Estuarine, Coastal and Shelf Science 57 (1-2): 313-323.

DOI: $10.1016 / \mathrm{S} 0272-7714(02) 00357-8$

Almeida P.R., Moreira F.M., Domingos I.M., Costa J.L., Assis C.A., Costa M.J. 1995. Age and growth of Liza ramada (Risso, 1826) in the River Tagus, Portugal. Scientia Marina 59 (2): 143-147.

Annabi A., Said K., Reichenbacher B. 2013. Interpopulation differences in otolith morphology are genetically encoded in the killifish Aphanius fasciatus (Cyprinodontiformes). Scientia Marina 77 (2): 269-279.

DOI: $10.3989 /$ scimar.03763.02A

Avigliano E., Callicó-Fortunato R., Buitrago J., Volpedo A.V. 2015. Is otolith microchemistry (Sr:Ca and $\mathrm{Ba}: \mathrm{Ca}$ ratios) useful to identify Mugil curema populations in the southeastern Caribbean Sea? Brazilian Journal of Biology 75 (4, Suppl. 1): 45-51.

DOI: $10.1590 / 1519-6984.01014$

Bahnasawy M., Khidr A., Dheina N. 2009. Seasonal variations of heavy metals concentrations in mullet, Mugil cephalus and Liza ramada (Mugilidae) from Lake Manzala, Egypt. Journal of Applied Sciences Research 5 (7): 845-852.

Bahri A. 1993. Évolution de la salinité dans un périmètre irrigué de la Basse Vallée de la Medjerda en Tunisie. Science du Sol 31 (3): 125-140.

Belgacem W., Langar H., Pergent G., Ben Hassine O.K. 2013. Associated mollusc communities of a Posidonia oceanica meadow in Cap Zebib (off North East Tunisia). Aquatic Botany 104: 170-175.

DOI: 10.1016/j.aquabot.2011.09.012

Ben Mammou A., Louati M.H. 2006. Évolution temporelle de l'envasement des retenues de barrages de Tunisie. Journal of Water Science 20 (2): 201-210. DOI: 10.7202/015813ar

Blel H., Chatti N., Besbes R., Farjallah S., Elouaer A., Guerbej H., Said K. 2008. Phylogenetic relationships in grey mullets (Mugilidae) in a Tunisian lagoon. Aquaculture Research 39 (3): 268-275. DOI: 10.1111/j.1365-2109.2007.01893.x

Boglione C., Costa C., Giganti M., Cecchetti M., Di Dato P., Scardi M., Cataudella S. 2006. Biological monitoring of wild thicklip grey mullet (Chelon labrosus), golden grey mullet (Liza aurata), thinlip mullet (Liza ramada) and flathead mullet (Mugil cephalus) (Pisces: Mugilidae) from different Adriatic sites: Meristic counts and skeletal anomalies. Ecological Indicators 6 (4): 712-732.
DOI: $10.1016 /$ j.ecolind.2005.08.032

Campana S.E. 1999. Chemistry and composition of fish otoliths: Pathways, mechanisms and applications. Marine Ecology Progress Series 188: 263-297. DOI: $10.3354 /$ meps 188263

Cardona L. 2006. Habitat selection by grey mullets (Osteichthyes: Mugilidae) in Mediterranean estuaries: The role of salinity. Scientia Marina 70 (3): 443-455.

Chang C.-W., Lin S.-H. Iizuka Y., Tzeng W.-N. 2004. Relationship between $\mathrm{Sr}: \mathrm{Ca}$ ratios in otoliths of grey mullet Mugil cephalus and ambient salinity: Validation, mechanisms, and applications. Zoological Studies 43 (1): 74-85.

Crampton J.S. 1995. Elliptic Fourier shape analysis of fossil bivalves: Some practical considerations. Lethaia 28 (2): 179-186.

DOI: 10.1111/j.1502-3931.1995.tb01611.x

Dakrory A.I., Ali R.S., Issa A.Z. 2012. Anatomical studied on the cranial nerves of Liza ramada (family: Mugilidae) nervus glossopharyngeus. Life Science Journal 9 (2): 86-93.

DOI: $10.7537 /$ marslsj090212.15

El-Dahhar A.A., Salama M.E., Moustafa Y.T., ElMorshedy E.M. 2013. Effect of using sea weeds in grey mullet (Liza ramada) larval diets on growth performance and feed utilization. Journal of the Arabian Aquaculture Society 8 (1): 217-228.

El-Ghobashy A.E. 2009. Ecological and biological assessment of a wild mullet fish fry Collection Station at the Egyptian Mediterranean water. World Journal of Fish and Marine Sciences 1 (4): 268-277.

El Zaeem S.Y. 2011. Phenotype and genotype differentiation between flathead grey mullet [Mugil cephalus] and thinlip grey mullet [Liza ramada] (Pisces: Mugilidae). African Journal of Biotechnology 10 (46): 9485-9492.

DOI: $10.13140 / 2.1 .1840 .9609$

Fehri-Bedoui R., Gharbi H., El Abed A. 2002. Période de reproduction et maturité sexuelle de Liza aurata (poisson, Mugilidae) des côtes est et sud tunisiennes. Bulletin de 1'Institut. National des Sciences et Technologies de la Mer de Salammbô 29: 11-15.

Fortunato R.C., Dura V.B., Volpedo A. 2014. The morphology of saccular otoliths as a tool to identify different mugilid species from the northeastern Atlantic and Mediterranean Sea Estuarine, Coastal and Shelf Science 146: 95-101. DOI: 10.1016/j.ecss.2014.05.013

Furlani D., Gales R., Pemberton D. (eds.) 2007. Otoliths of common Australian temperate fish; A photographic guide. CSIRO Publishing, Collingwood, VIC, Australia.

Froese R., Pauly D. (eds.) 2016. FishBase. [Version 10/2016] www.fishbase.org

Glamuzina B., Dulčić J., Conides A., Bartulović V., MatićSkoko S., Papaconstantinou C. 2007. Some biological parameters of the thin-lipped mullet Liza ramada (Pisces, Mugilidae) in the Neretva River delta (eastern Adriatic, Croatian coast). Vie et Milieu 57 (3): 7-13. 
Göçer M., Ekingen G. 2005. Comparisons of various bony structures for the age determination of Liza ramada (Risso, 1826) population from the Mersin Bay. Ege University Journal of Fisheries and Aquatic Sciences 22 (1-2): 211-213.

Jónsdóttir I., Campana S.E., Marteinsdottir G. 2006. Stock structure of Icelandic cod Gadus morhua L. based on otolith chemistry. Journal of Fish Biology 69 (Suppl. sc): 136-150.

DOI: $10.1111 / \mathrm{j} .1095-8649.2006 .01271 . x$

Jonsson B., Jonsson N. 2008. Thinlip grey mullet Liza ramada (Mugilidae) caught in a small Norwegian stream. Fauna norvegica 26/27: 31-33.

DOI: $10.5324 /$ fn.v26i0.571

Kalay M., Sangün K.M., Ayas D., Goçer M. 2008. Chemical composition and some trace element levels of thinlip mullet, Liza ramada caught from Mersin Gulf. Ekoloji 17 (68): 11-16.

DOI: 10.5053/ekoloji.2008.682

Kasımoğlu C., Yılmaz F. 2012. Feeding habits of the thin-lipped grey mullet, Liza ramada, in Gökova Bay in the southern Aegean Sea (Osteichthyes: Mugilidae). Zoology in the Middle East 56 (1): 55-61.

DOI: 10.1080/09397140.2012.10648941

Kuhl F.P., Giardina C.R. 1982. Elliptic Fourier features of a closed contour. Computer Graphics and Image Processing 18 (3): 236-258.

DOI: 10.1016/0146-664X(82)90034-X

Laffaille P., Feunten E., Lefebvre C., Radureau A., Sagan G., Lefeuvre J.-C. 2002. Can thin-lipped mullet directly exploit the primary and detritic production of European macrotidal salt marshes? Estuarine, Coast and Shelf Science 54 (4): 729-736. DOI : 10.1006/ecss.2001.0855

Limburg K.E., Walther B.D., Lu Z., Jackman G., Mohan J., Walther Y., Nissling A., Weber P.K., Schmitt K.A. 2015. In search of the dead zone: Use of otoliths for tracking fish exposure to hypoxia. Journal of Marine Systems 141: 167-178.

DOI: 10.1016/j.jmarsys.2014.02.014

Lombarte A., Lleonart J. 1993. Otolith size changes related with body growth, habitat depth and temperature. Environmental Biology of Fishes 37 (3): 297-306.

DOI: $10.1007 / \mathrm{BF} 00004637$

Masmoudi W., Romdhane M.S., Kheriji S., EL Cafsi M. 2001. Variation de l'accumulation du lindane chez les alevins de Liza ramada. Bulletin de l'Institut. National des Sciences et Technologies de la Mer de Salammbô 28: 113-117.

Mehanna F.S. 2006. Fisheries management of the thinlip grey mullet Liza ramada and golden grey mullet Liza aurata from lake Bardawil, Egypt. Egyptian Journal of Aquatic Biology and Fisheries 10: 33-53.

Merella P., Garippa G. 2001. Metazoan parasites of grey mullets (Teleostea: Mugilidae) from the Mistras Lagoon (Sardinia, western Medtiterranean). Scientia Marina 65 (3): 201-206.

DOI: $10.3989 /$ scimar.2001.65n3201
Midway S.R., Cadrin S.X., Scharf F.S. 2014. Southern flounder (Paralichthys lethostigma) stock structure inferred from otolith shape analysis. Fishery Bulletin 112: 326-338.

DOI: $10.7755 / F B .112 .4 .9$

Neves A., Sequeira V., Vieira A.R., Paiva R.B., Gordo L.S. 2015. Age and growth of small red scorpionfish, Scorpaena notata (Actionopterygii: Scorpaeniformes: Scorpaenidae), a common discard species from the Portuguese fishery. Acta Ichthologica et Piscatoria 45 (1): 13-20. DOI: $10.3750 / A I P 2014.45 .1 .02$

Nirchio M., Ron E., Rossi A.R. 2005. Karyological characterization of Mugil trichodon: Pory, 1876 (Pisces: Mugilidae). Scientia Marina 69 (4): 525-530. DOI: $10.3989 /$ scimar.2005.69n4525

Panfili J., De Pontual H., Troadec H., Wright P.J. (eds.) 2003. Manuel de sclérochronologie des poissons. Coédition Ifremer-IRD, France.

Papasotiropoulos V., Klossa-Kilia E., Kilias G., Alahiotis S. 2002.Genetic divergence and phylogenetic relationships in grey mullets (Teleostei: Mugilidae) based on PCR-RFLP analysis of mtDNA segments. Biochemical Genetics 40 (3): 155-168.

DOI: $10.1023 / \mathrm{A}: 1015162304934$

Rabeh I., Telahigue K., Chetoui I., Masmoudi W., El Cafsi M. 2010. The effects of low salinity on lipid composition in the gills of grey mullet Liza ramada. Bulletin de 1'Institut National des Sciences et Technologies de la Mer de Salammbô 37: 65-73.

Radhakrishan K.V., He W., Liu M., Xie S. 2009. Otoliths - the biological CD-ROMs of fish. Current Science 97 (8): 1121-1122.

Rebaya M., Ben Faleh A., Allaya H., Khedher M., Marsaoui B., Chalh A., Quignard J.-P., Trabelsi M. 2016. Morphological variability of saccular otoliths in two populations of Liza ramada (Risso, 1810) (Mugilidae) in Tunisian lagoons (Bizerte and Ghar El Melh). Cahiers de Biologie Marine 57: 227-234.

Reichanbacher B., Reichard M. 2014. Otoliths of five extant species of the annual killifish Nothobranchius from the East African savannah. PLoS ONE 9 (11): e112459.

DOI: 10.1371/journal.pone.0112459

Trojette M., Ben Faleh A.R., Fatnassi M., Marsaoui B., Mahouachi N., Chalh A., Quignard J.-P., Trabelsi M. 2015. Stock discrimination of two insular populations of Diplodus annularis (Actinopterygii: Perciformes: Sparidae) along the coast of Tunisia by analysis of otolith shape. Acta Ichthyologica et Piscatoria 45 (4): 363-372.

DOI: 10.3750/AIP2015.45.4.04

Trojette M., Fatnassi M., Ben Alaya H., Mahouachi N., Chalh A., Quignard J.P., Trabelsi M. 2014. Applying sagitta otolith shape in the discrimination of fish populations Scorpaena porcus (Linnaeus, 1758) (Scorpaenidae) in the Tunisian coasts. Cahiers de Biologie Marine 55 (4): 499-506. 
Turki S., Ktari-Chakroun F. 1985. Ichtyoplancton du golfe de Tunis. Bulletin de l'Institut national scientifique et technique d'Océanographie et de pêche 12: 5-24.

Volpedo A.V., Vaz-dos-Santos A.M. (eds.) 2015. Métodos de estudios con otolitos: principios y aplicaciones; Métodos de estudos com otólitos: princípios e aplicações. Consejo Nacional de Investigaciones Científicas y Técnicas, Buenos Aires, Argentina.
Yacoub A., Abdel Satar A.M. 2003. Heavy metals accumulation and macronutrients in the livers of some fish species of Bardawil lagoon and their histological changes. Egyptian Journal of Aquatic Biology and Fisheries 7 (4): 403-422.

Received: 4 May 2016 Accepted: 24 November 2016 Published electronically: 31 March 2017 